\title{
Swedes Studying Abroad - as Tourists?
}

\author{
Per A. Nilsson ${ }^{1, *} \&$ Thomas Blom² \\ ${ }^{1}$ Department of Geography, Umeå University, Sweden \\ ${ }^{2}$ Department of Geography, Media and Communication, Karlstad University, Sweden \\ *Correspondence: Planning Office, Umeå University, SE-901 87 Umeå, Sweden, Tel: 46-907-866-866. E-mail: \\ per.a.nilsson@umu.se
}

Received: September 24, 2020

Accepted: October 16, $2020 \quad$ Online Published: October 18, 2020

doi:10.5430/wje.v10n5p98

URL: https://doi.org/10.5430/wje.v10n5p98

\begin{abstract}
The number of students temporarily studying in another country to receive a post-secondary education has grown significantly since the 1970s. This study aims to learn more about what attracts Swedish outbound students when studying abroad. What are the popular study destinations? Can data reveal touristic preferences? Descriptive statistics from the Swedish Board of Student Finance are used, making it possible to scrutinize studying abroad on an aggregate level over a period of two decades. The results show that English-speaking countries are attractive to Swedish outbound students. Places growing in popularity are the countries of Poland, Japan, the Netherlands, South Korea, Singapore, and China, as well as the region of Hong Kong in particular. However, more than 50 percent of outbound students study in Europe. In these troubling and uncertain times, we are living in, with COVID-19 and other crises hampering worldwide travel, it is difficult to predict the long-term effects on mobility.
\end{abstract}

Keywords: outbound students, Sweden, studying-abroad tourism

\section{Introduction}

Many young adults in the European/Western context have had a desire to explore the world by traveling, working, and/or studying abroad (Altbach \& Knight, 2007; Nilsson, 2019). This has to do with better purchasing power, cheaper flight tickets and a worldwide connectivity, as well as new routes having opened up (Hall, 2005a; Hall, 2005b). In our global economy, student mobility is part of the tourism industry. In tourism and hospitality research, students studying abroad would be defined as tourists as they are temporarily mobile like all other tourists. Thus, the interpretation is that the students will relocate to other places temporarily, implying at least an ambition to return to their place of departure. International students show similarities with tourists when it comes to choosing their study destination. Students' choices of destination do not depend on existing networks within the world of academia alone and/or academic achievements; they can have other preferences outside the domain of academia. Some scholars have recognized that the growth of youth travel includes a blend of traveler types, such as the tourist, the volunteer, the language student, the exchange student, and the intern (Richards, 2015).

Swedish students receive financial support for studies abroad, provided by the Swedish Board of Student Finance (CSN - Centrala studiestödsnämnden), thus offering them an opportunity many students in the world are lacking (CIMO et al., 2013). Outbound Swedish students are somewhat privileged, as higher education institutions (HEI) in the Nordic countries are publicly funded, with strong influence from egalitarian traditions viewing them as an important pillar in the building of a welfare system (Börjesson et al., 2014). This also includes studying abroad having been conceptualized as an asset to the country as well as an opportunity for the student to have an international experience.

This article scrutinizes outbound Swedish students who take with them a study loan. Studying abroad at the post-secondary level includes categories such as degree student, exchange student, and language student. A degree student is one who arranges their own education at a foreign HEI. An exchange student studies abroad within the framework of an exchange program organized by the HEI in Sweden via an agreement with a foreign university; the studies abroad can be recognized as part of the student's education in Sweden. A language student is one who is studying a foreign language abroad. Previous studies have shown that students have expectations before a sojourn abroad: they report desires to travel, to experience another culture, and to enhance their language skills as motives 
for studying abroad (e.g. Teichler 2002; Bracht et al., 2006; Choudaha, 2017). Some of their motives are like those of any other tourist, wanting to explore other countries and cultures to have an experience outside Sweden.

International students have similarities to regular tourists. They are both visiting other countries temporarily, but with different durations. The United Nations World Tourism Organization (UNWTO) defines a tourist based on the activities a person undertakes upon traveling to a destination, and moreover, the duration of the travel. To be defined as a tourist, the person's stay has to be less than a year for leisure, business, or other purposes (United Nations, 2010). This study aims to learn more about mobility patterns among Swedish outbound students and what attracts students who temporarily study abroad, covering a period of two decades. When exploring descriptive data from the study aid system (CSN), a number of questions can be addressed:

- What are the popular study destinations for Swedes studying abroad?

- Does data reveal touristic preferences when studying abroad?

- Can we say anything about why study destinations rise and fall in popularity?

- Does data reveal information about barriers hindering mobility and/or drivers of mobility?

\section{Literature Review}

Youth travel can be seen in a broad context of mobility. Narratives about mobility and mobile practice are described by Cresswell (2010). A motive force answers the question of why a person moves. There is a degree of necessity in relation to mobility when choosing to move or not. A student can either be pushed to move, or move due to personal choice. Motive force can be applied to a student before they actually move: there are positive forces serving as pull factors, such as wanting to study abroad or at a particular HEI; and there are negative forces serving as push factors, such as a lack of study opportunities at home or wanting to leave one's country. Velocity is a concept referring to how quickly a person can move. Being able to get somewhere quickly is increasingly associated with exclusivity - as something for those who have the resources. Thus, velocity suggests inequalities such as students' socioeconomic background and what they can afford in relation to tuition fees, living costs, transportation, etc. As a routine, mobility, as part of the reproduction of everyday life, can be conceptualized as a rhythm. For international students, a global intervention can change the rhythm - interrupt or disturb it - when they want to travel to a study destination abroad; for instance, through tightened visa regulations targeting international students from specific countries. The idea of a route implies that mobility does not happen evenly over a continuous space. Some studies have found that students describe mobility as an intensely personal experience (Papatsiba, 2005). As friction, mobility can be stopped or slowed down, as well as increase when transportation costs decrease or new routes are opened.

There are many categories of students who take part in international travel. Knight (2012) identifies six: (i) moving to a foreign country to enroll and complete a full degree at a host institution; (ii) studying within their home institution's degree program while undertaking a short-term (one semester or one year) mobility experience in a foreign country at a foreign institution, or at a branch campus of their home institution; (iii) enrolling in an education program involving two or more HEIs or providers working collaboratively to offer a degree program; (iv) conducting research or fieldwork in fulfilment of a degree program at their home institution; (v) participating in a required or optional internship, placement, or work fulfilment for a degree program at their home institution; (vi) undertaking a required or optional study tour, summer program, cultural or language course, conference, or workshop.

One could argue that international students are part of the tourism industry because they are temporarily mobile like all other tourists. However, compared to regular tourists, international students are mostly planning to stay abroad longer at a particular place than a regular tourist would. Tuan (2011) stresses that it is important to get to know the neighborhood and specific locations in order to thrive in a place when one plans to stay for a longer duration. By spending a longer period in one place, it is possible to get to know it from other aspects than a traditional tourist usually does. Initially, we experience new places from an "outside perspective", before we know the culture that exists and can attain a deeper understanding. However, over time, we become part of the place and embrace the culture there and can then have an "inside perspective". Most traditional tourists will rarely have time to gain such an experience. There are several studies that show how the site-related identity is strengthened by the time spent on the site. This is often referred to as place attachment (Lewicka, 2010). Thus, someone's feeling for a place is influenced by their knowledge about it (Tuan, 2011).

The significance of the place where a student chooses to study, relatively speaking, is largely analogous to how a tourist reasons when choosing a traditional tourist trip. The different attributes and the identity of a place generate a value that is perceived as attractive and, furthermore, create expectations (e.g. Relph, 1976; Rose, 1995; Tilley, 
2006). For this reason, Plog $(1974 ; 2001)$ attempts to understand why destinations and resorts rise and fall in popularity. Destinations attract different groups of consumers/tourists. Analogously, it can be assumed that different study destinations, i.e. the city or region where a university is located, attract different students. Jonsson (2003) showed that some Swedish students were attracted by study destinations far from Sweden. Others, mostly less experienced travelers, looked for options closer to their home university. The conclusion Plog draws is that different personality characteristics determine travel patterns and preferences. It might be the most adventurous and internationally experienced students who are attracted to enrolling in studying abroad, as an opportunity for exploration. The choices students make about mobility are individualistic, and it seems as if they place a very high value on their choice of country in which to study. Swedish studies have shown that the country is more important than the study destination (Jonsson, 2003) and, furthermore, that for most students the study destination is more important than the university itself (Nilsson, 2019).

The decision to study abroad is complex for the student and many aspects are included, for instance the choice of country and the HEI. Mazzarol and Soutar (2002) identified knowledge and awareness of the host country, personal recommendations, cost issues, environment, geographic proximity, and social links as being of great importance in this decision.

Over time, the attractiveness of a destination can change (e.g. Plog, 1974; 2001). In general, stories in various forms about what a place can offer are significant for the tourism industry. Analogously, this is true when students make their final choice of the place of study (e.g. Jonsson, 2003; Nilsson, 2019). Morgan, Lugosi, and Ritchie (2010) emphasize that stories about places and the experiences available there consist mainly of three factors: (i) how the place - in this case, the university - is marketed; (ii) tourists' (or former students') own stories; and (iii) stories and actions of those who represent the place and the university. Some scholars argue that the significance of the story through previous students' experiences is a particularly important factor, as these stories consolidate the value of the place and the university, shaping the image and attractiveness of the place (Bosangit, McCabe \& Hibbert, 2009).

The international student exchange of our time, at both secondary and post-secondary levels, is not a late-modern phenomenon. There are several parallels between today's tourism and students' choices when studying abroad with the educational journeys of the $18^{\text {th }}$ and $19^{\text {th }}$ centuries in Europe. This type of educational trip, called a Grand Tour, was a final part of one's education and could last several years. Paris was usually the first city visited, followed by the larger Italian cities such as Turin, Milan, Florence, Rome, Naples, and Venice (Wolf, 2001). British author Samuel Johnson (1709-1784) wrote the following in 1776 as an explanation of why it was so important to embark on a journey to the Mediterranean region and gain new knowledge and experience; "A man who has not been in Italy, is always conscious of an inferiority, from his not having seen what it is expected a man should see" (Ratcliffe, 2017).

It was common during this period to spend some time at a university, to later move on to another in order to acquire different types of knowledge (Towner, 1996). English philosopher and statesman Francis Bacon (1561-1626) formulated the following ideals for these educational journeys (Karlsson, 1994):

- One should master the language of the countries you intend to visit.

- One should strive to meet prominent people.

- Among other things, one should visit churches, monasteries, defense installations, coronations, executions, and trading houses.

\section{Research Method}

The Swedish Board of Student Finance (CSN) is the government agency that manages Swedish student finance; i.e., grants and loans for studies. Its database contains information on all Swedes studying at HEIs who receive CSN aid: approximately 300,000 Swedes study with financial aid each semester, which corresponds to 71 percent of all Swedish students (CSN, 2020). These numbers include both domestic students and those studying abroad. This study was guided by a desire to explore studying abroad among Swedish outbound students, using descriptive analysis of information from the CSN database. Descriptive statistics are used to describe the basic features of Swedish outbound students, and the data makes it possible to scrutinize studying abroad on an aggregate level over a period of two decades. Hence, in this study an approach has been chosen that attempts to account for change over a longer period, from the 2001/2002 academic year until 2018/2019. This allows for a comparison of mobility patterns among Swedish outbound students and an assessment of any change that may have occurred.

Furthermore, the data presented includes any type of study financial aid paid during the selected time period. It should be noted that this study only discusses Swedish outbound students who take with them grants and loans for 
studying abroad, and does not cover all the aspects and specific dimensions of being a foreign student.

\section{Results}

Swedish study loans enable approximately 23,000 outbound students annually (corresponding approximately to the size of a fairly large Swedish university) to study abroad. The vast majority of those who study abroad are female, which corresponds approximately to the female share of the total student population, 60 percent (CSN, 2019).

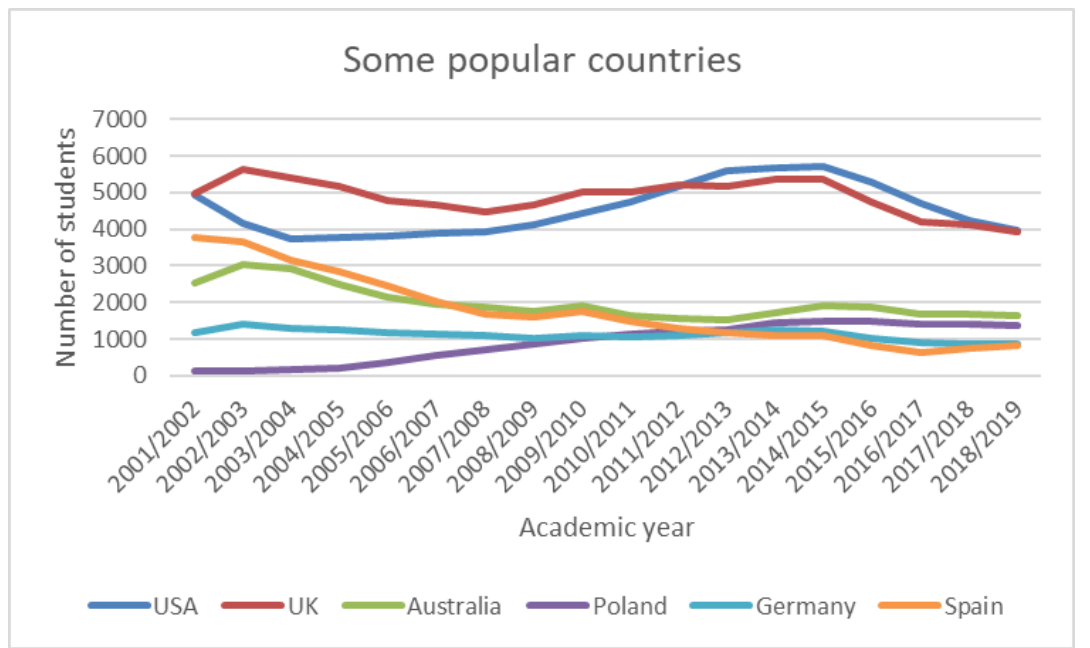

Figure 1. Popular Countries, Total Numbers per Academic Year for Swedish Outbound Students

Source: CSN, 2019

English-speaking countries are attractive to Swedish outbound students, for whom the US and the UK are the reigning champions of countries to study in (Figure 1). This is thanks to their many prestigious universities, and the attraction also involves a wish to remain in the country after graduating in order to work and live there. Thus, being an English-speaking country seems to be a major attraction for Swedes. We find some countries - for instance Germany, which has a large number of prestigious universities spread out across many cities - to not be as popular among Swedish outbound students as one would imagine, even though Germany is an economic powerhouse of Europe. Still, more than 50 percent of Swedish outbound students study in Europe and 20 percent in North America (CSN, 2019).

As shown, the US and the UK take the top spots for Swedish students studying abroad (Figure 1). However, places like Poland, Japan, the Netherlands, South Korea, Singapore, Hong Kong, China, and Canada are on the rise (Table 1). The increasing numbers of Swedes studying in Poland can be explained by the fact that 968 Swedes studied at medical schools in Poland, out of a total of 2,071 Swedes at medical schools abroad during the 2018/2019 academic year (CSN, 2019). This indicates that Swedish outbound students prefer to study in English-speaking countries or where the courses are taught predominantly in English. Countries like the US and the UK have been top destinations for decades, but have lost some of their attractiveness among outbound Swedish students. However, growth is noticeable among Swedes studying in Asia. Most HEIs in Asia offer many courses taught in English. The number of Swedish students studying in Asia has grown by approximately 500 percent, starting at 400 students during the 2001/2002 academic year and growing to 2,322 two decades later, amounting to approximately 10 percent of Swedish outbound students (CSN, 2019). The decline in students particularly in Spain and France can be explained by a change in regulations in 2015 allowing only a limited number of language courses to be eligible for grants and loans for studying abroad. 
Table 1. Places Gaining vs. Losing in Popularity among Swedish Outbound Students. Source: CSN, 2019.

\begin{tabular}{|c|c|c|c|}
\hline \multicolumn{4}{|c|}{ Academic year/Number of students } \\
\hline & $2001 / 2002$ & $2018 / 2019$ & Gain $(+) / \operatorname{Loss}(-)$ \\
\hline Poland & 114 & 1366 & +1252 \\
\hline Japan & 124 & 780 & +656 \\
\hline The Netherlands & 364 & 895 & +531 \\
\hline South Korea & 15 & 445 & +430 \\
\hline Singapore & 73 & 440 & +367 \\
\hline Hong Kong & 16 & 313 & +297 \\
\hline China & 50 & 339 & +289 \\
\hline Canada & 374 & 659 & +285 \\
\hline Thailand & 17 & 149 & +132 \\
\hline Taiwan & 11 & 118 & +107 \\
\hline Mexico & 39 & 132 & +93 \\
\hline Spain & 3768 & 1367 & -2401 \\
\hline France & 2465 & 943 & -1522 \\
\hline Australia & 2529 & 1731 & -798 \\
\hline UK & 4981 & 4198 & -783 \\
\hline US & 4952 & 4246 & -706 \\
\hline Italy & 1067 & 639 & -428 \\
\hline Norway & 892 & 668 & -224 \\
\hline Denmark & 1317 & 1132 & -185 \\
\hline Germany & 1189 & 1005 & -184 \\
\hline Finland & 336 & 199 & -137 \\
\hline Chile & 200 & 89 & -111 \\
\hline New Zealand & 226 & 137 & -89 \\
\hline
\end{tabular}

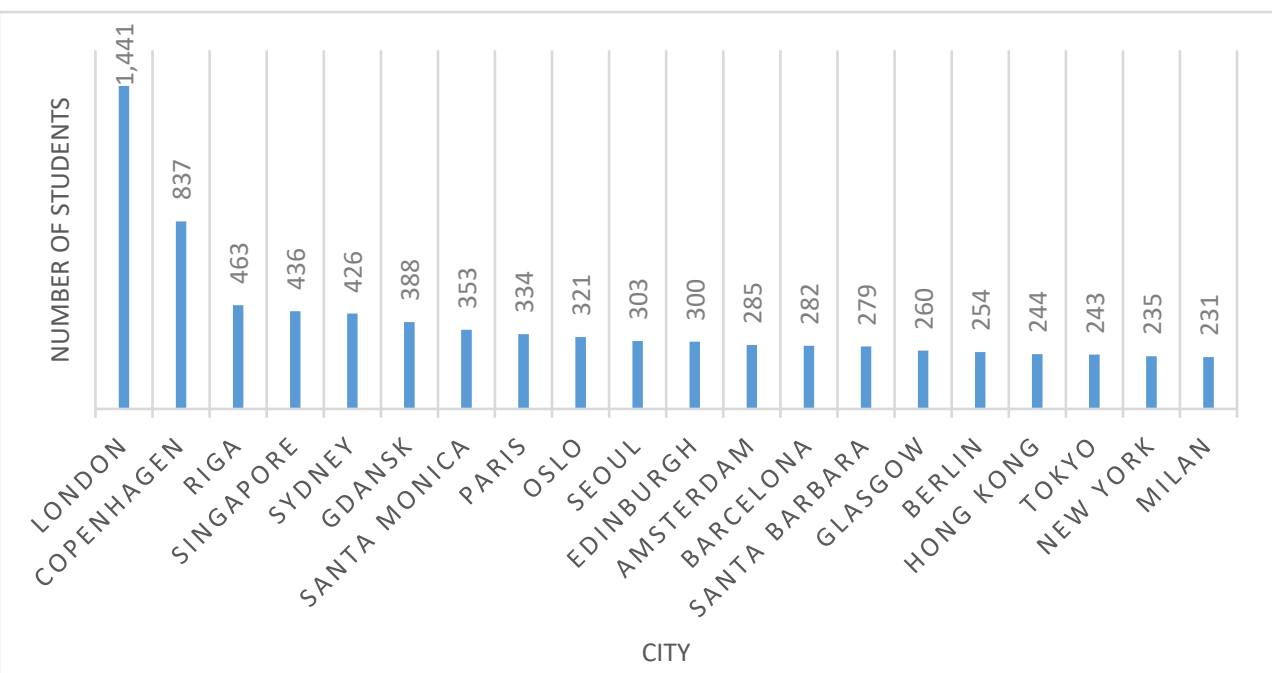

Figure 2. Popular Cities for Swedish Outbound Students at the Post-secondary Level for Academic Year 2018/19. Source CSN, 2019 
It is noticeable that big cities attract Swedish outbound students (Figure 2). Large metropoles can also offer many prestigious HEIs. Copenhagen, Denmark, is the largest capital city among the Nordic countries, and for this reason is attractive to Swedes. Almost 400 Swedish students studied medicine in Riga, Latvia, in 2019. We know that Asia is growing in popularity among outbound Swedish students. Some more or less target life outside academia, such as students studying at community colleges in Santa Monica and Santa Barbara in the US. While a diploma from a community college is not a recognized degree in the Swedish higher education system (CSN, 2018), the vast majority of students study at well recognized HEIs around the world (Table 2).

Table 2. Top HEIs with More than 100 Outbound Swedish Students Enrolled in Post-secondary Education for Academic Year 2018/19 (CSN, 2019).

\begin{tabular}{llcc}
\hline Higher education institution (HEI) & City, country & Number of students & QS World \\
& & 447 & University Ranking \\
\hline Rīga Stradinš University & Riga, Latvia & 387 & Yes \\
Copenhagen Business School & Copenhagen, Denmark & 373 & Yes \\
Medical University of Gdansk & Gdansk, Poland & 353 & N/A \\
Santa Monica College & Santa Monica, USA & 234 & N/A \\
Santa Barbara City College & Santa Barbara, USA & 207 & Yes \\
Nanyang Technological University & Singapore & 181 & Yes \\
Lithuanian University of Health Sciences & Kaunas, Lithuania & 173 & Yes \\
University of Edinburgh & Edinburgh, UK & 161 & Yes \\
University of Aberdeen & Aberdeen, UK & 155 & Yes \\
National University of Singapore & Singapore & 155 & Yes \\
Wroclaw Medical University & Wroclaw, Poland & 154 & Yes \\
The Royal Danish Academy of Fine Arts & Copenhagen, Denmark & 141 & Yes \\
Copenhagen University & Copenhagen, Denmark & 137 & Yes \\
University of Glasgow & Glasgow, UK & 136 & N/A \\
University of Varmia and Masuria & Olsztyn, Poland & 133 & Yes \\
University College London & London, UK & 116 & Yes \\
University of the Sunshine Coast & Maroochydore, Australia & 109 & Yes \\
University van Amsterdam & Amsterdam, Netherlands & 108 & Yes \\
Kyung Hee University & Seoul, South Korea & 105 & Yes \\
Kings College London & London, UK & 105 & Yes \\
Politecnico di Milano & Milan, Italy & 104 & Yes \\
Medical University Sofia & Sofia, Bulgaria & & \\
\hline & & & \\
\hline
\end{tabular}

\section{Discussion and Conclusion}

This study aimed to learn more about mobility patterns and what attracts outbound Swedish students who temporarily study abroad. The findings indicate that Swedish outbound students prefer to study in English-speaking countries, with those such as the US and the UK being top destinations for decades. This has also been indicated in other studies (King et al., 2010). However, a decline in this is noticeable since the turn of the millennium and instead a growth in popularity is observed among other countries, mainly in Asia. It seems as if big, vibrant cities attract Swedish outbound students.

Students are looking for experiences and training in different parts of the world. In a broader context, word-of-mouth can be important when choosing a study destination. There is often a certain inertia in terms of students' tendency to choose other HEIs than previous students within their education have chosen before them. When it comes to choosing a specific attractive program, such as medical school, the education and the degree are primary. The touristic aspect is likely stronger when it comes to undergraduate students choosing to study a semester or two abroad. It is noticeable that outbound students have more options than they are willing and/or able to use when it comes to studying outside Sweden. The search for adventure seems to bring the outbound students to cities like 
London, Singapore, and Sydney, while those with medical studies in mind end up in cities like Riga and Gdansk. The warmer climate and beaches appear to bring Swedish outbound students to community colleges in Santa Monica and Santa Barbara. Even though a diploma from a community college is not recognized as a post-secondary education in the Swedish higher education system (CSN, 2018), students are still taking loans to study at places whose credits cannot be transferred to an undergraduate degree at a Swedish HEI.

The descriptive analyses provide some interesting indications regarding countries that are attractive to Swedes when studying abroad, especially considering that they are doing this with study loans, which have to be repaid to the Swedish government within 25 years. This suggests that the students are investing in their future career and life, which also seems to actually be the case. Swedish students are most likely to be enrolled in HEIs with a recognized high academic standard, most of them on the QS World University Ranking list. Furthermore, Swedish students might have mixed motives when studying abroad, for instance wanting to study at a highly recognized university located in a city and/or country that is attractive to the student. Some have to study where they are admitted, regardless of their preference of city and/or country, and do not really have a choice if they are aiming to, for example, become a physician.

The data reveals how changes in regulations can effect studying abroad. In 2015 a change in regulations took place, allowing only language courses at the post-secondary level to be eligible for grants and loans for studying abroad. The consequence of these new regulations was that the number of language students dropped considerably. This is also an example of how political decisions can either encourage mobility or make it more difficult, or even prevent it. This study shows that the numbers of outbound students to Spain, France, and Italy dropped by 40-70 percent since the turn of the millennium due to changes in regulations regarding receiving a loan to study a foreign language.

\section{Implications}

When reviewing previous studies on international student mobility, one notes that they cover a number of issues. Academic achievement is the most essential for some students, while for others the study destination comes first (Sutton \& Rubin, 2004; Malmgren \& Galvin, 2008). The outcomes of some studies indicate that educational and career choices are important among international students (Bracht et al., 2006). This study indicates a wish to study at a prestigious university outside Sweden, driven by a desire for academic achievement, as well as a preference to live in a specific country or city outside Sweden. The vast majority of students study in Europe, but an increasing number of those studying in Asia can be observed. However, Swedish students studying in another Nordic country still make up a significant number. There are studies indicating that countries that speak the same language as international students have much larger flows of these students than those that do not share the same language (Abbot \& Silles, 2016). To some extent this is also true for Swedes studying in countries like Denmark and Norway, as well as English-speaking countries, as many Swedes are able to study in English. English is mandatory in Swedish schools from the third grade on, and most students have good proficiency in English. For Swedes, studying in the UK has been very attractive. It remains to be seen whether this will continue to be the case among Swedes in the aftermath of Brexit, or if the flow of outbound Swedish students will take another direction. It is obvious that exchange students are linked with partner universities via formal agreements. Exchange students' choice of destination depends on existing networks and formal agreements with HEIs outside Sweden.

However, during 2020, COVID-19 has changed much when it comes to the possibility to take part in international student mobility. A large number of universities around the world have suspended all international student exchanges. At the same time, new opportunities are rapidly being developed to allow students to gain international experience without traveling. In addition to the various digital learning platforms available today, new innovations in the area of distance education are being presented, which in various ways offer new opportunities for mobility. This will likely also create other opportunities for many of the students who previously, not least for socioeconomic reasons, found it difficult to spend a semester or two at a foreign university during their education. But even with the possibilities to find solutions through digital teaching methods, students will lack the cultural experiences of actually living abroad; the physical meeting with students and the social interaction will be absent. It is difficult to foresee what implications this will have on international knowledge-sharing, having other experiences and perspectives from abroad while integrating with peers. At the same time, the changed situation due to COVID-19 may mean that students' 'digital mobility' is increasingly affected by universities' academic status and ranking, as the geographical location is not a factor in the choice of university today. It will therefore be interesting to study how the current situation involving mobility affects future geographical choices of university. 
Thus, new concepts for having an international experience need to be developed; not only in relation to the COVID-19 pandemic but also to the United Nations Sustainable Development Goals addressing global challenges such as poverty, inequality, climate change, environmental degradation, peace, and justice. While this might result in less long-distance travel, it also offers opportunities to take advantage of the possibility for ICT to serve as a leveler of inequality and injustice in the world, which may have the consequence that the geographical localization in the choice of university for studies abroad takes on a different significance.

\section{References}

Abbot, A., \& Silles, M. (2015). Determinants of international student migration. The World Economy, 39(5), 621-635. https://doi.org/10.1111/twec.12319

Altbach, P. G., \& Knight, J. (2007). The Internationalization of Higher Education: Motivations and Realities. Journal of Studies in International Education, 11(3-4), 290-305. https://doi.org/10.1177/1028315307303542

Bracht, O., Engel, C., Janson, K., Over, A., Schomburg, H., \& Teichler, U. (2006). The Professional Value of ERASMUS Mobility. Final report of the VALERA project. International Centre for Higher Education Research (INCHER-Kassel), University of Kassel, Kassel, Germany

Bosangit, C., McCabe, S., \& Hibbert S. (2009). What is Told in Travel Blogs? Exploring Travel Blogs for Consumer Narrative Analysis. In: Höpken W., Gretzel U., Law R. (eds) Information and Communication Technologies in Tourism 2009. Springer, Vienna. https://doi.org/10.1007/978-3-211-93971-0_6

Börjesson, M., Ahola, S., Helland, H., \& Thomsen, J-P. (2014). Enrolment Patterns in Nordic Higher Education, ca 1945 to 2010. Institutions, Types of Education and Fields of Study. Working Paper 15/2014. Nordic Institute for Studies in Innovation. Research and Education (NIFU). Oslo. Retrieved from: http://curis.ku.dk/ws/files/131533276/NIFUworkingpaper2014_15.pdf

Choudaha, R. (2017). Three Waves of International Student Mobility (1999-2020). Studies in Higher Education, 825-832. https://doi.org/10.1080/03075079.2017.1293872

CIMO (Centre for International Mobility), UHR (Swedish Council for Higher Education) and SIU (Norwegian Centre for International Cooperation in Education) (2013). Living and learning - exchange studies abroad. A study of motives, barriers and experiences of Finnish, Norwegian and Swedish students. Retrieved from https://www.uhr.se/globalassets/syv/utlandsvistelse/euroguidance/fler-rapporter/28083_living_and_learning.pdf

Cresswell, T. (2010). Towards a politics of mobility. Environment and Planning D: Society and Space, 28, 17-31. https://doi.org/10.1068/d11407

CSN (2020). Vilka studerar utan studiemedel? Report 2020:1. Stockholm, Sweden. Retrieved from https://www.csn.se/download/18.25c8284616ffa19f1e7a0f/1585641615784/Vilka\%20studerar\%20utan\%20stud iemedel.pdf

CSN (2019). The Swedish Government authority in charge of financial aid. Retrieved from https://statistik.csn.se/PXWeb/pxweb/sv/CSNstat/?rxid=1874bc3e-fef6-4c7e-b506-115ca290535c

CSN (2018). Studerande vid Community Colleges USA. Report 2018:6. Stockholm, Sweden. Retrieved from https://www.csn.se/download/18.6f417a0165fbcb61634b9/1538556885830/Studerande\%20vid\%20Community \%20Colleges\%20i\%20USA\%20slutrapport.pdf

Hall, C. M. (2005a). Space-time accessibility and the tourist area cycle of evolution: the role of geographies of spatial interaction and mobility in contributing to an improved understanding of tourism, in R. Butler (ed) The Tourism Life Cycle: Conceptual and Theoretical Issues, 2, 83-100. Channelview Publications Clevedon.

Hall, C. M. (2005b). Tourism: Re-thinking the Social Science of Mobility. Harlow: Prentice-Hall.

Jonsson, G. (2003). Rotad, rotlös rastlös, GERUM kulturgeografi 2003, 3 (Umeå University Press, Sweden).

Karlsson, S-E. (1994). Natur och kultur som turistiska produkter. Research Report 94, 11, Karlstad University, Sweden.

King, R., Findlay, A., \& Ahrens, J. (2010). International student mobility literature review. Reported to HEFCE, and cofounded by the British Council, UK National Agency for Erasmus.

Knight, J. (2012). Student mobility and internationalization: trends and tribulations. Research in Comparative and International Education, 7(1), 20-33. https://doi.org/10.2304/rcie.2012.7.1.20 
Lewicka, M. (2010). Place attachment: How far have we come in the last 40 years? Journal of Environmental Psychology, 31, 207-230. https://doi:10.1016/j.jenvp.2010.10.001

Malmgren, J., \& Galvin, J. (2008). Effects of study abroad participation on student graduation rates: A study of three incoming freshman cohorts at the University of Minnesota, Twin Cities. NACADA Journal, 28(1), 29-42.

Mazzarol, T., \& Soutar, G. (2002). Push-Pull Factors Influencing International Students Destination Choice. International Journal of Educational Management, 16, 82-90. https://doi.org/10.1108/09513540210418403

Morgan, M., Lugosi, P., \& Ritchie, J. B. (Eds.). (2010). The tourism and leisure experience: Consumer and managerial perspectives, 44. Channel View Publications.

Nilsson, P. A. (2019). Studying Abroad. Exploring mobility, expectations and experiences among mobile students. Department of Geography. Kulturgeografi 2019, 2. (Umeå University Press, Sweden).

Papatsiba, V. (2005). Political and Individual Rationales of Student Mobility: a case-study of ERASMUS and a French regional scheme for studies abroad. European Journal of Education, 2, 173-188. https://doi.org/10.1111/j.1465-3435.2004.00218.x

Plog, S. C. (1974). Why Destination Areas Rise and Fall in Popularity. Cornell Hospitality Quarterly, 14(4), 55-58. https://doi.org/10.1177/001088047401400409

Plog, S. C. (2001). Why destination areas rise and fall in popularity: an update of a Cornell Quarterly classic. Cornell Hotel and Restaurant Administration Quarterly, 42(3), 13-24. Doi: 10.1016/S0010-8804(01)81020-X

Ratcliffe, S. (Ed.). (2017). Oxford Essential Quotations (5th ed.). Oxford University Press. https://doi:10.1093/acref/9780191843730.001.0001

Relph, E. (1976). Place and Placelessness. London: Pion. https://doi: 10.4135/9781446213742.n5

Richards, G. (2015). The new global nomads: Youth travel in a globalizing world. Tourism Recreation Research. https://doi:10.1080/02508281.2015.1075724

Rose, G. (1995) Place and identity: a sense of place: Massey, D. \& Jess, P. (red.) The shape of the world: explorations in human geography, 4. A place in the world? places, cultures and globalization. Oxford University Press, New York.

Sutton, R. C., \& Rubin, D. L. (2004). The GLOSSARI project: Initial findings from a system-wide research initiative on study abroad learning outcomes. Frontiers: The Interdisciplinary Journal of Study Abroad, 10, 65-82.

Teichler, U. (2002). Erasmus in the Socrates programme. Findings of an evaluation study. Bonn, Lemmens.

Tilley, C. (2006). Introduction: Identity, Place, Landscape and Heritage. Journal of Material Culture, 7-32. https://doi.org/10.1177/1359183506062990

Towner, J. (1996). An historical geography of recreation and tourism in the Western world, 1540-1940. Chichester; New York: John Wiley.

Tuan, Y-F. (2011). Space and place. The perspective of Experience. University of Minnesota Press. USA. Eighth Printing.

UHR (2019). Vägen till utlandsstudier. Report from Swedish Council for Higher Education 2019, 5. Stockholm.

United Nations (2010). International Recommendations for Tourism Statistics 2008. Department of Economic and Social Affairs. Statistics Studies in Methods. Series M No. 83/Rev.1. Retrieved from https://unstats.un.org/unsd/publication/seriesm/seriesm_83rev1e.pdf

Wolf, E. (2001). Med charter till Estoril, Department of Ethnology. Gothenburg University, Sweden. 


\section{Copyrights}

Copyright for this article is retained by the author(s), with first publication rights granted to the journal.

This is an open-access article distributed under the terms and conditions of the Creative Commons Attribution license (http://creativecommons.org/licenses/by/4.0/). 